\title{
A Study on the Planning and Use of Common Space in Private Rental Apartments in Okinawa, Japan
}

\author{
Kyeonghwa Byun*¹, Shunsuke Fukushima ${ }^{2}$ and Kotaroh Hirate ${ }^{3}$ \\ ${ }^{1}$ Graduate Student, Department of Architecture, Graduate School of Engineering, University of Tokyo, Japan \\ ${ }^{2}$ Representative, Dr. Engineer, Archipelago Environmental and Cultural Design, Japan \\ ${ }^{3}$ Professor, Department of Architecture, Graduate School of Engineering, University of Tokyo, Japan
}

\begin{abstract}
This study aims to clarify the plan and use of common space in private rental apartments in Okinawa, Japan. The study covers the establishment of pilotis and non-pilotis style apartments by site area, the types of common spaces, and the use and evaluation of common spaces. To accomplish this, architectural drawings of 110 private rental apartments and a questionnaire sent to residents are fully analyzed. The results are as follows. First, the establishment of pilotis or non-pilotis style buildings is influenced by the site area and existence of exterior space. Pilotis style apartments without exterior space tend to be built on small sites. Next, common space is classified into four groups by building type and location of space: no common space (NCS), pilotis space only (PSO), shared pilotis space and exterior space (PSES) and exterior space only (ESO). Pilotis space is substituted for exterior space in non-pilotis style apartments and in common space shared pilotis space and exterior space, pilotis space supports exterior space functionally. Third, the main function of common space is for parking. Finally, according to the result of the evaluation of common space, PSO residents regard parking positively and the environment negatively, PSES residents regard parking neutrally and the environment positively, and ESO residents regard parking negatively and the environment neutrally.
\end{abstract}

Keywords: Common space; exterior space; pilotis space; site area; private rental apartment; Okinawa; evaluation by residents

\section{Introduction}

\subsection{Background and Purpose}

Okinawa Prefecture, Japan's southernmost prefecture, consists of about 160 large and small islands, of which 50 are inhabited, in a chain over $1,000 \mathrm{~km}$ in length and $400 \mathrm{~km}$ in width. In Okinawa Prefecture, housing started to be made of reinforced concrete with the arrival of the US Army at the end of World War II. Okinawa has a climate with a high level of humidity and high temperatures. The introduction of reinforced concrete allowed the development of pilotis style buildings, which have an open ground floor and are suitable for Okinawa's climate. Pilotis style buildings are now firmly established as a common architectural form in Okinawa.

Therefore, these two points of historical appearance and climate have become the focus of mainstream studies on pilotis style buildings in Okinawa. Other studies on these buildings have focused on the structure

\footnotetext{
* Contact Author: Kyeonghwa Byun, Department of Architecture, Graduate School of Engineering, University of Tokyo, 7-3-1, Hongo, Bunkyo-ku, Tokyo, 113-8656 Japan Tel: +81-3-5841-6166 Fax: +81-3-5841-6167

E-mail: byun@env.arch.t.u-tokyo.ac.jp

(Received October 8, 2007 ; accepted March 6, 2008)
}

of pilotis ${ }^{1}$ or pilotis style housing ${ }^{2}$ itself.

The pilotis space in a pilotis style building has the ambilateral spatial characteristics of semi-interior or semi-exterior space. It is difficult to conclusively refer to it as interior space or exterior space because it has both functions. In other words, the space is spatially mediated by location and communal use in multiunit housing. Okinawa is experiencing a rapid increase in automobile use compared to other areas of $\mathrm{Japan}^{3}$, and pilotis style buildings lend themselves to providing space for parking. Thus, the functional use of pilotis space has become more important.

In addition, one of the significant components contributing to the quality and enjoyment of any living environment is the common space between and around buildings. Well-planned common space has positive environmental impacts in the form of improved natural lighting and airflow to private units. For apartment housing, common space plays an intermediary role by connecting the private and public areas and also functions as necessary space, such as entrance areas and parking for residents. However, common space in private rental apartment buildings tends to be planned in a way that increases the number of units rather than providing adequate common space, due to the fact that apartments tend to be constructed with a limited 
budget.

According to the study, Articulation and Layout of Exterior Space ${ }^{4}$, exterior space can be classified into two types: arranged exterior space and articulated exterior space. In this study, this division is used by adopting exterior space as a common space in private rental apartment buildings. Arranged exterior space is used as exterior space existing outside the building, and articulated exterior space refers to pilotis space.

In the study, The Open Space of Multifamily Housing in the Tokyo Built-up Area, researchers analyzed the architectural conditions and reasons for open space. They classified open space into two groups, inner open space and outer open space based on the building layout, site area and relation to roads. In this study, these classifications are used to distinguish pilotis and non-pilotis style buildings via the openness of the ground floor, and the types of common space are classified by their location.

There is a meaningful study on pilotis style housing in Okinawa: Spatial Characteristics of Pilotis-type Detached Housing Based on Housing Needs and Dwelling Usage 6 , in which the researchers clarified that the pilotis style was decided by residents rather than architects during the planning process. However, in this study, the background to the establishment of pilotis style and non-pilotis style apartments is focused on the influencing rather than deciding factors such as the site area and building coverage ratio.

In this study, the common space of a private rental apartment is considered in terms of the spatial and environmental mediation between its private and public use. In detail, upon going from the road to a private unit, the first common space is the exterior space between the building and the road. The second common space is the communal space between the private units and the building, such as the pilotis space, entrances, staircases, hallways, elevators, and the common laundry room. In this study, however, these typical and functionally-planned spaces are not the focus. In this study, common space is classified into four types in terms of pilotis structure and the existence and location of space: no common space, pilotis space only, shared pilotis space and exterior space and exterior space only.

The main purpose of this study is to clarify the planning and use of common space in private rental apartments on Okinawa Island, Japan, in order to provide significant data for the future planning and design of common space in multiunit housing. This study has three main sections:

1) Establishment of common space

2) Types of common space

3) Use and evaluation of common space

\subsection{Data Collection and Method of Study}

The data for this study were collected from 42 architectural design offices that were located in Okinawa and members of the Okinawan Society of
Architecture and Building Engineers as well as a questionnaire answered by residents.

This study includes a full analysis of 110 private rental apartments on the basis of architectural drawings and an information request form about these buildings that was filled out by the designers. The four types of architectural drawings studied were site plans, floor plans, elevations and sections. Examples of private rental apartments were limited to three cases per architectural design office to ensure that various designs and ideas were represented. The information request form about the private rental apartments consisted of general data including site area and building coverage ratio. The data were collected in October and November of 2005.

Questionnaires were distributed to the residents who lived in the private rental apartments for which the authors collected architectural drawings for this study. The questionnaire asked about residents' sociodemographic status and their level of satisfaction with the exterior appearance and space, the facilities of the common space, and the parking area. Out of a total of 984 units, 580 (58.9\% of the total) were given questionnaires. The total number of units in the 110 private rental apartments was 1,020 but six buildings that were under construction (36 units) were excluded. Excluding use in the questionnaire however, data from the six apartments was collected after completion in 2006 and was used in the study.

Only 53 questionnaires were collected, which was a return rate of just $9.14 \%$. However, no consideration was given to vacant units. The distribution and collection of questionnaires was conducted from May to June of 2006.

The methods used in this study were architectural drawing analysis, field investigation, interviews with designers and an analysis of the questionnaires.

\section{General Information on Apartments}

Table 1. shows the five categories of general information considered for the 110 private rental

Table 1. Categories of General Information

\begin{tabular}{|c|c|c|c|}
\hline \multicolumn{2}{|r|}{ Category } & $\mathrm{N}$ & $\%$ \\
\hline \multirow{4}{*}{$\begin{array}{c}\text { Year } \\
\text { Completed }\end{array}$} & Before 1990 & 5 & 4.5 \\
\hline & $1991-1995$ & 9 & 8.2 \\
\hline & $1996-2000$ & 20 & 18.2 \\
\hline & $2001-2006$ & 76 & 69.1 \\
\hline \multirow{2}{*}{ Material } & Reinforced concrete & 109 & 99.1 \\
\hline & Steel-reinforced concrete & 1 & 0.9 \\
\hline \multirow{3}{*}{$\begin{array}{l}\text { Number } \\
\text { of Stories }\end{array}$} & 2-3 stories & 60 & 54.6 \\
\hline & $4-5$ stories & 39 & 35.5 \\
\hline & $6-10$ stories & 11 & 9.9 \\
\hline \multirow{2}{*}{$\begin{array}{l}\text { Building } \\
\text { Type }\end{array}$} & Pilotis style building & 67 & 60.9 \\
\hline & Non-pilotis style building & 43 & 39.1 \\
\hline \multirow{6}{*}{$\begin{array}{l}\text { Land Use } \\
\text { Designated } \\
\text { Districts }\end{array}$} & $\begin{array}{l}\text { Category } 1 \text { or } 2 \text { : Exclusively } \\
\text { Low-rise Residential District }\end{array}$ & 34 & 30.9 \\
\hline & $\begin{array}{l}\text { Category } 1 \text { or } 2 \text { : Exclusively } \\
\text { Medium-high Residential District }\end{array}$ & 30 & 27.3 \\
\hline & Category 1 or 2 : Residential District & 20 & 18.2 \\
\hline & Quasi-residential District & 3 & 2.7 \\
\hline & $\begin{array}{l}\text { Neighborhood Commercial } \\
\text { District or Commercial District }\end{array}$ & 9 & 8.2 \\
\hline & Mixed-use District & 14 & 12.7 \\
\hline & Total & 110 & 100.0 \\
\hline
\end{tabular}


apartments studied, which were located in eight cities, four towns and one village.

Seventy-six apartments were completed between 2001 and 2006 , which was $69.1 \%$ of the total. The oldest apartment was completed in 1988. Reinforced concrete was the most common building material $(99.1 \%)$, with only one apartment made of steelreinforced concrete. This supports the assertion that $99 \%$ of housing in Okinawa is constructed with reinforced concrete.

Single-story buildings were not included in this study. All buildings examined were between two and 10 stories. Of the private rental apartments in the study $90 \%$ of them were from two to five stories tall. Among them, three-story buildings were the most common (52 cases, $47.3 \%$ ), followed by four-story apartments (28 cases, $25.5 \%$ ).

There were 67 pilotis style apartments (60.9\%). It is thought that pilotis style buildings are firmly established as a common architectural form in Okinawa. Comparing pilotis and non-pilotis style buildings by year (Fig.1.), since 1996, the number of pilotis style buildings has rapidly increased. Among the 110 apartments studied, before 1996 there were slightly fewer pilotis than non-pilotis style buildings. By 2006, the number of pilotis style buildings had dramatically risen and was double the number of non-pilotis style buildings.

Eighty-seven private rental apartments (79.1\%) were located in residential districts, nine apartments were in commercial districts, and 14 were in mixed-use districts.

\section{Establishment of Common Space}

\subsection{Site Area and Building Coverage Ratio}

For the 110 private rental apartments, to clarify the establishment of pilotis and non-pilotis style buildings, the site area and building coverage ratio (BCR) were compared, as shown in Table 2 and Fig. 2.

The average site area of the 110 private rental apartments was $533.9 \mathrm{~m}^{2}$, and site areas ranged from $89.70 \mathrm{~m}^{2}$ to $2,245.0 \mathrm{~m}^{2}$. Comparing the site areas of the two types of buildings, the average site area of the 67 pilotis style buildings was $474.8 \mathrm{~m}^{2}$ while the average site area of the 43 non-pilotis style buildings was $626.07 \mathrm{~m}^{2}$. The site areas of pilotis style buildings were around $200 \sim 400 \mathrm{~m}^{2}$, compared with $43.3 \%$ (29 cases) of the 67 pilotis style buildings. The site areas of the non-pilotis style buildings were more evenly spread out across the whole range of area sizes.

Comparing the BCR, the average of all 110 buildings was $50.93 \%$ and ranged from $14.33 \%$ to $87.77 \%$. The average BCR of the 67 pilotis style buildings was $56.2 \%$ and that of the 43 non-pilotis style buildings was $42.86 \%$. The distribution of BCR for the nonpilotis style buildings was spread out while that for the pilotis style buildings was concentrated.

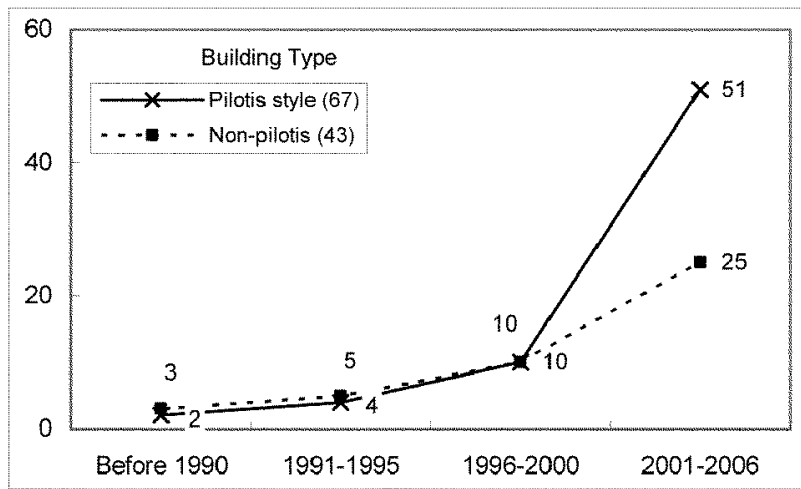

Fig.1. Type of Apartments by Year

Table 2. Site Area

\begin{tabular}{c|c|c|c}
\hline Site area & Pilotis & Non-pilotis & Total (\%) \\
\hline Less than $100 \mathrm{~m}^{2}$ & 0 & 2 & $2(1.8)$ \\
\hline $100-$ less than $200 \mathrm{~m}^{2}$ & 9 & 2 & $11(10.0)$ \\
\hline $200-$ less than $300 \mathrm{~m}^{2}$ & 15 & 7 & $22(20.0)$ \\
\hline $300-$ less than $400 \mathrm{~m}^{2}$ & 14 & 4 & $18(16.4)$ \\
\hline $400-$ less than $500 \mathrm{~m}^{2}$ & 8 & 5 & $13(11.8)$ \\
\hline $500-$ less than $600 \mathrm{~m}^{2}$ & 6 & 4 & $10(9.1)$ \\
\hline $600-$ less than $700 \mathrm{~m}^{2}$ & 6 & 4 & $10(9.1)$ \\
\hline $700-$ less than $800 \mathrm{~m}^{2}$ & 2 & 3 & $5(4.5)$ \\
\hline $800-$ less than $900 \mathrm{~m}^{2}$ & 1 & 3 & $4(3.6)$ \\
\hline $900-$ less than $1000 \mathrm{~m}^{2}$ & 1 & 3 & $4(3.6)$ \\
\hline $1000-$ less than $2000 \mathrm{~m}^{2}$ & 5 & 5 & $10(9.1)$ \\
\hline More than $2000 \mathrm{~m}^{2}$ & 0 & 1 & $1(0.9)$ \\
\hline Total & 67 & 43 & $110(100 \%)$ \\
\hline
\end{tabular}

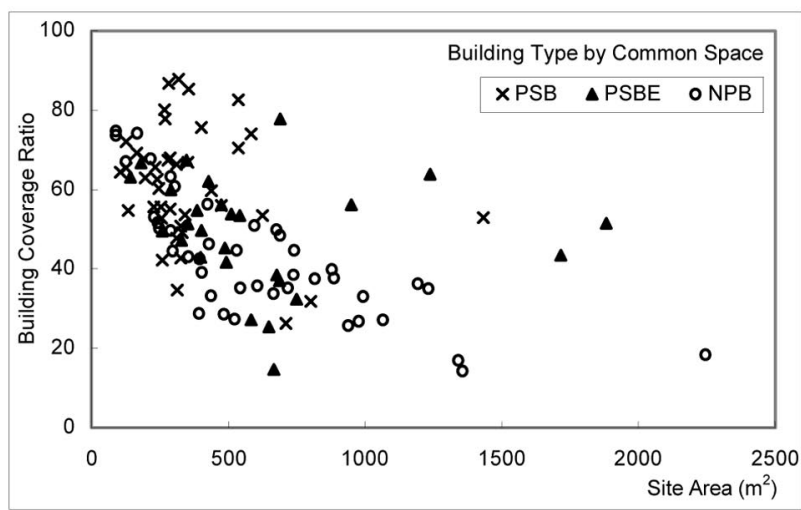

PSB ( $\times$ ): Pilotis style building without exterior space $\operatorname{PSBE}(\boldsymbol{\Delta})$ : Pilotis style building with exterior space NPB (O): Non-pilotis style building

Fig.2. Distribution of Site Area and Building Coverage Ratio

Table 3. ANOVA Analysis of Site Area and BCR

\begin{tabular}{c|c|c|c|c}
\hline Building Type (N) & PSB (40) & PSBE (27) & NPB (43) & Average \\
\hline Site Area $\left(\mathrm{m}^{2}\right)^{* *}$ & 382.03 & 612.18 & 626.07 & 533.92 \\
\hline BCR (\%) * $^{* * *}$ & 60.65 & 49.37 & 42.86 & 50.93 \\
\hline
\end{tabular}

PSB: Pilotis style building without exterior space PSBE: Pilotis style building with exterior space NPB: Non-pilotis style building

BCR: Building coverage ratio

When investigating the common space of pilotis style buildings, the authors noted that there were 27 buildings with planned exterior space among the 67 pilotis style buildings. Therefore, the 67 pilotis style apartments were divided into two groups: with and without planned exterior space. As a result, the 110 
buildings were classified into three groups: pilotis style buildings without exterior space (PSB), pilotis style buildings with exterior space (PSBE), and non-pilotis style buildings (NPB).

The differences in the site area and BCR were examined by ANOVA analysis for the three types of buildings and the results are shown in Table 3.

The site areas and BCR of these building groups were considerably different, however, the differences between PSB and the two other groups were statistically significant, while the differences between PSBE and NPB were not.

The site areas of PSB and PSBE were significantly different even though they both contained pilotis style buildings. According to Table 3, the average site area of PSBE is more than 1.5 times that of PSB. It can be concluded that PSBs are more frequently constructed on smaller sites than PSBEs. However, PSBE and NPB have no statistically significant difference in site area. Therefore, it can be understood that the choice of pilotis style or non-pilotis style is one option when the site area is large, but the pilotis style is necessary in the case of a small site. Because it is difficult to provide adequate exterior space in a small site, pilotis space is used for common space as a substitute for exterior space.

The building groups show significantly different values of $\mathrm{BCR}$, but not to the extent of the difference in site area between PSB and the other two groups. The BCR of buildings without exterior space is undoubtedly higher, irrespective of whether they have a pilotis style or not. BCRs for PSBE and NPB show no significant difference even though both contained planned exterior spaces.

For private rental apartments in Okinawa, pilotis style apartments without exterior space are planned at smaller sites and have a high BCR. Pilotis style and non-pilotis style apartments with planned exterior space exhibit no significant difference in site area or BCR.

\subsection{Forms of Pilotis Space}

Pilotis space is categorized into six forms on the basis of topographic features and the open or closed quality of the space, as shown in Table 4.

Pilotis forms A, B and C are planned for buildings on entirely flat land and forms D, E and F are used for buildings on uneven land. Forms D, E and F accounted for just seven cases while forms A, B and C accounted for almost $90 \%$ of the 67 cases. Form A occurred the most often (32 cases), and was mainly observed at sites with areas of 200 to $400 \mathrm{~m}^{2}$. Buildings of form C were generally seen at large sites, and the average site area for form $\mathrm{C}$ was $1,022.47 \mathrm{~m}^{2}$. In the case that the topographic features were uneven, some buildings of types D, E and F had two entrances, one on the higher level and one on the lower level.

Regarding the open or closed quality of pilotis space, entirely pilotis forms A and D were more frequently constructed at smaller sites. All six cases with site areas of more than $900 \mathrm{~m}^{2}$ were semi-pilotis style apartments.

Form F (where pilotis space covers two stories of the building), accounted for one case. Form F was planned for a building where two roads were located to the front and rear of the building, but were at different topographic levels.

\section{Types of Common Space}

The common space planned in the 110 private rental apartments in this study was classified into four types in terms of pilotis structure and the existence and location of space: no common space in non-pilotis style buildings, pilotis space only in pilotis style buildings, shared pilotis space and exterior space in pilotis style buildings and exterior space only in non-pilotis style buildings, as shown in Table 5.
A. NCS - no common space ( 2 cases)
B. PSO - pilotis space only (40 cases)
C. PSES - shared pilotis space and exterior space
(27 cases)
D. ESO - exterior space only (41 cases)

Moreover, PSES and ESO, with planned exterior space, were further classified according to the spatial relationship between the exterior space and the building.

\subsection{No Common Space (NCS)}

Two of the 110 private rental apartments had no planned common space. The site areas of these two cases were the smallest among all the samples $\left(89.7 \mathrm{~m}^{2}\right.$ and $\left.90 \mathrm{~m}^{2}\right)$ and the BCRs $(73.8 \%$ and $74.7 \%)$ were the highest among the non-pilotis buildings. The ground floors were used for commercial space and the buildings were planned with only one unit per floor.

The land use of the sites was designated as Category 1 or 2 Exclusively Low-story Residential use. The buildings are located in the Shuri area of Naha, which is the oldest town in Okinawa. They were completed in 1990 and 1991.

Table 4. Forms of Pilotis Space by Topographic Features and Open/Closed Qualities

\begin{tabular}{|c|c|c|c|c|c|c|c|}
\hline Site & & & 12 & & & $\square$ & $N$ \\
\hline $\begin{array}{l}\text { Open or } \\
\text { Closed }\end{array}$ & Entirely Pilotis & Semi-Pilotis & $\begin{array}{l}\text { Semi-Pilotis } \\
\text { Center Closed }\end{array}$ & Entirely Pilotis & Semi-Pilotis & $\begin{array}{c}\text { Semi-Pilotis } \\
2 \text { Levels } \\
\end{array}$ & \\
\hline Topography & Entirely Flat & Entirely Flat & Entirely Flat & Uneven & Uneven & Uneven & \\
\hline Type (N) & $\mathrm{A}(32)$ & $\mathrm{B}(23)$ & $\mathrm{C}(5)$ & $\mathrm{D}(4)$ & $E(2)$ & $F(1)$ & 67 \\
\hline
\end{tabular}




\subsection{Pilotis Space Only (PSO)}

Pilotis space as the only planned common space occurred in 40 cases. These apartments were generally built at smaller sites and their average site area was $382.03 \mathrm{~m}^{2}$, lower than the average site area of pilotis style buildings, $474.8 \mathrm{~m}^{2}$. In addition, they had a high average BCR of $60.65 \%$, compared with the average BCR of pilotis style apartments, $56.2 \%$.

Regarding the pilotis form, form A (entirely flat and entirely open) accounted for 23 out of 40 cases followed by form B (semi-pilotis and entirely flat), which accounted for nine cases.

\subsection{Shared Pilotis Space and Exterior Space (PSES)}

PSES occurred in 27 cases and exhibited six forms in terms of the relationship between the exterior space and the building, as shown in Table 5 .

PSES-a, where the exterior space is adjacent to one side of the building, was the most common form (13 cases). All other forms had exterior spaces adjacent to two or more sides of the building. In these cases, pilotis space and exterior space support each other to increase the use of the spaces; for example, PSES-b and PSES-f, pilotis space plays a connecting role between two separate exterior spaces. A car or people can pass through the pilotis space to access the exterior space. Therefore, use of the pilotis and exterior spaces is improved.

\subsection{Exterior Space Only (ESO)}

The number of cases where common space existed only in the form of exterior space was 41 . This type showed the most variety of forms, with eight different relationships between exterior space and the building. In particular, ESO-d and ESO-h were not observed for the other types of plan.

The form in which exterior space was adjacent to only one side of the building was the most common, as for PSES ( 25 out of 41 cases).

Compared with PSES, two separate exterior spaces are connected via the pilotis space, but for ESO, two or more different exterior spaces in the site are connected to each other, except for ESO-b and ESO-h.

A typical case was ESO-b, in which a section was opened in the building. For convenient vehicular access, the building had a tunnel connecting two roads

Table 5. Types of Common Space by Space Location

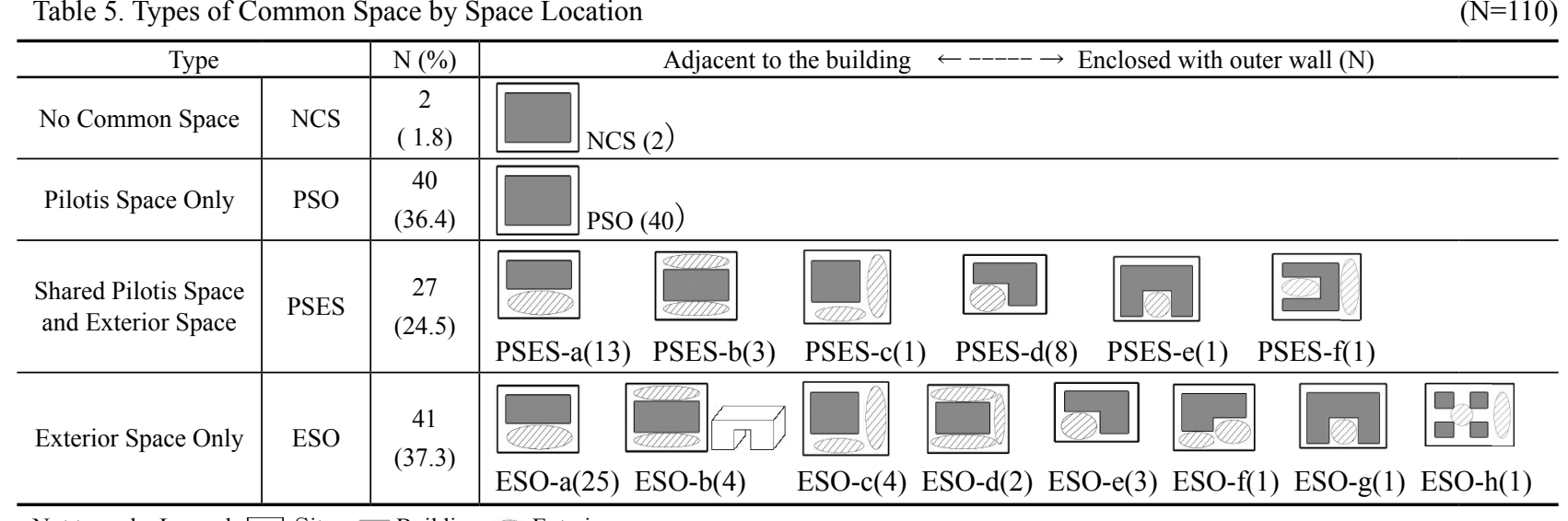

Not to scale Legend: $\square$ Site Building $\square$ Exterior space

to the front and rear of the building. In the case of ESO-h, the exterior space was planned as a courtyard and was enclosed with four independent buildings. This case is the only one in this study in which the exterior space was not connected to a parking lot. In this case, the parking lot was located to one side of the site.

\section{Use and Evaluation of Common Space 5.1 Use of Common Space}

The common space considered in this study is used for several reasons, as shown in Table 6. Common space was planned from the beginning by the designers, but residents often found new ways of using the space without regard to the original plans.

The most frequent usage of common space was for utilities and services such as water, gas, electricity, fire extinguishers and post boxes. However, most of these facilities were not planned to have their own space, but were set up in the common space.

The largest area and the most frequently used among the functions considered was the parking area. Common space was used for parking in 108 out of the 110 private rental apartments, and the other two cases were those for which common space was not provided. Planned parking space is very important in multiunit housing because of the high population density relative to private homes. Parking is particularly important in Okinawa because the rate of automobile use is increasing and the rate of ownership is increasing at a higher rate than in other areas of Japan.

Table 6. Use of Common Space

\begin{tabular}{l|l}
\hline Function & Details \\
\hline Utilities and services & $\begin{array}{l}\text { Electricity, water, gas, } \\
\text { fire extinguisher, post box }\end{array}$ \\
\hline Parking & Car, motorcycle, bicycle \\
\hline Relaxing and entertainment & Rest, play \\
\hline Green space & Flower garden, trees, gardening \\
\hline Signs & Gate, housing name board \\
\hline Consumption & Vending machine \\
\hline Temporary storage & Separate garbage collection \\
\hline Information & Notice board \\
\hline Facilities & Washing space for pets \\
\hline Religion & Ihai (ancestral tablet) \\
\hline
\end{tabular}

$(\mathrm{N}=110)$ 
Typically, common space planned for relaxing and playing was limited and exterior space specifically for garden use was uncommon in this study. Exterior space planned as a courtyard for gardening or as a passageway comprised only one case. Archways, name boards and sculptures laid out in the exterior space occurred in 15 cases. These have symbolic roles but little or no functional use.

Fig.3. shows unique usage of pilotis space. The left picture shows an area designed as a washing space for pets. Ihai, an ancestral tablet, was installed in the pilotis space shown in the picture to the right. Because no personal space is provided outside the private units, pilotis space can be adapted for personal use such as the Ihai.

There were 33 buildings with shops located on the ground floor or vending machines set up in the common space for residents or visitors.

Results from the information request form sent to designers regarding the functions of pilotis space in pilotis style apartments are shown in Fig.4. Parking was the most frequent response with 56 of 67 cases and was followed by storage space ( 2 cases). Anticrime measures and future use accounted for one case each. Play space, working space, ventilation, and the prevention of $\mathrm{Habu}$ snakes were listed as possible responses but were not chosen.

Pilotis space that was not used for parking space occurred in only one case in this study. In this case, the building was situated in the center of the site and parking space was provided in the exterior space to the front and rear of the building, so the pilotis space was used only as a passage connecting the front and rear spaces.

To analyze parking in the 110 private rental apartments, the book, Plans and Building Knowledge of Rental Housing Schemes ${ }^{7}$, was consulted. In this book, it is stated that the number of car spaces that should be available is $\lceil$ the number of units $\times 0.5 \sim 0.7\rfloor$ for apartments for Japanese residents and $\lceil$ the number of units $\times 1 \sim 1.5\rfloor$ for apartments for foreign residents.

The amount of parking was classified into six levels, as shown in Table 7. In this study, units in which the owners of the rented apartments live are included in the number of units but shops are not.

There are two private rental apartments with no parking spaces. $\lceil 1 \sim 1.5 \mathrm{p} / \mathrm{unit}\rfloor$, the level recommended for apartments housing foreign residents has the most cases $(60.9 \%)$, followed by 21 cases of more than $1.5 \mathrm{p} / \mathrm{unit}$. Those two levels account for 88 cases $(80 \%$ of the apartments). Because of the above guidelines the planning and provision of parking space in Okinawa is relatively good compared with other areas of Japan.

\subsection{Residents Satisfaction with Common Space}

To investigate the level of resident satisfaction with common space, residents were grouped by the type of common space (PSO, PSES and ESO) and their socio-
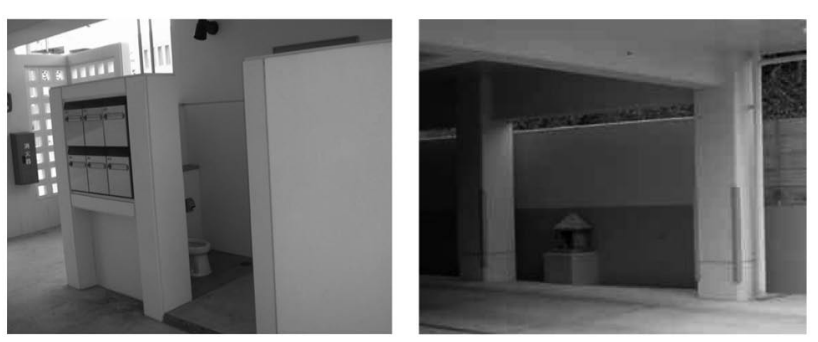

Fig.3. Use of Common Pilotis Space

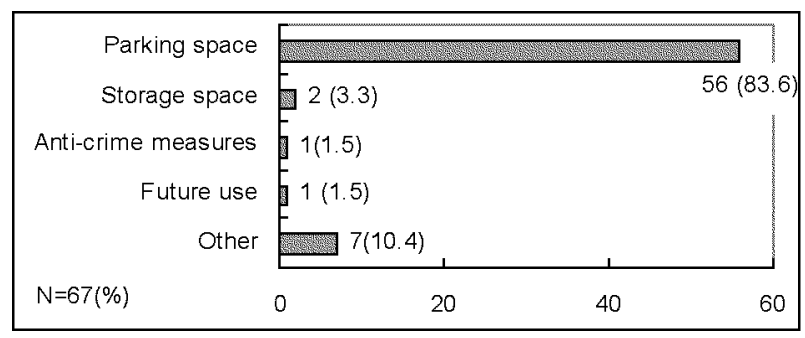

Fig.4. Functions of Pilotis Space

Table 7. Number of Car Spaces Available

\begin{tabular}{l|c|c}
\hline Amount of Parking & $\mathrm{N}$ & $\%$ \\
\hline No parking spaces & 2 & 1.8 \\
\hline Less than $0.5 \mathrm{p} / \mathrm{unit}$ & 5 & 4.5 \\
\hline $0.5-0.7 \mathrm{p} / \mathrm{unit}$ & 13 & 11.8 \\
\hline $0.7-1 \mathrm{p} /$ unit & 2 & 1.8 \\
\hline $1.0-1.5 \mathrm{p} /$ unit & 67 & 60.9 \\
\hline More than $1.5 \mathrm{p} /$ unit & 21 & 19.1 \\
\hline Total & 110 & 100.0 \\
\hline
\end{tabular}

Source: Plans and building knowledge of rental housing schemes, p. 57.

p: Number of car lots available

Table 8. Socio-demographic Statistics of Residents

\begin{tabular}{|c|c|c|c|c|c|c|c|}
\hline \multicolumn{2}{|c|}{ Index } & $\mathrm{N}$ & $\%$ & \multicolumn{2}{|c|}{ Index } & $\mathrm{N}$ & $\%$ \\
\hline \multirow{2}{*}{ Sex } & Female & 30 & 56.6 & \multirow{6}{*}{ Age } & Teens & 2 & 3.8 \\
\hline & Male & 23 & 43.3 & & 20 's & 15 & 28.3 \\
\hline \multirow{4}{*}{$\begin{array}{l}\text { No. of } \\
\text { Cars } \\
\text { Owned }\end{array}$} & No cars & 8 & 15.1 & & 30 's & 22 & 41.5 \\
\hline & $1 \mathrm{car}$ & 32 & 60.4 & & 40 's & 5 & 9.4 \\
\hline & 2 cars & 11 & 20.8 & & 50 's & 5 & 9.4 \\
\hline & 3 cars & 2 & 3.8 & & 60's & 4 & 7.5 \\
\hline & Total & 53 & 100.0 & & Total & 53 & 100.0 \\
\hline
\end{tabular}

demographic profile, as shown in Table 8. There was no response to the questionnaire from those living in apartments without common space (NCS).

A study into the satisfaction regarding common space by residents in terms of exterior appearance, exterior environment, the facilities of the common space and the parking space was conducted. Questions regarding parking space asked about location, size, and brightness at night. The satisfaction is rated from 1 to 5 , with 1 point indicating the lowest satisfaction. The results of the questionnaire are shown in Fig.5.

The largest use of common space according to the residents was for parking (Table 6.). Designers also responded that parking use takes the largest proportion of common space in their plans (Fig.4.). Therefore, half of the six questions are related to parking issues due to Okinawan residents' high rate of car ownership.

Comparing the average of those six variables, the facilities of the common space showed the lowest satisfaction with an average of 2.77 , and the brightness 
of the parking lot at night had the highest average at 3.47. The average score for exterior appearance was 3.4, exterior space was 3.06, and the location and size of the parking lot were 3.21 and 3.19, respectively.

There was a significant difference in satisfaction with the exterior appearance, the location and size of the parking lot, and the brightness of the parking lot at night for residents living in apartments with different types of common space. PSES residents were the most satisfied with the exterior appearance, exterior environment, size of the parking lot, and the brightness of the parking lot at night, but there was no statistical difference concerning satisfaction with the exterior environment. However, PSO residents were the most satisfied with the location of the parking lot. It is thought that this is because parking spaces inside the pilotis space make it easier to approach the main entrance or the main staircase than exterior parking space.

As a whole, PSES residents were more satisfied and ESO residents less satisfied than other residents. In particular, ESO residents were the least satisfied with the size of the parking lot, which suggests that new parking plans for exterior spaces are needed.

To examine the interdependence of these six variables, factor analysis was conducted, as shown in Table 9. The six variables were considered as two principal factors: factor 1 constituted the exterior appearance, exterior environment, the facilities of the common space, and the brightness of the parking lot at night. Factor 2 constituted the location and the size of the parking lot. The two factors were named environment (factor 1) and parking (factor 2).

Fig.6. shows the distribution of the factor scores of 53 residents. The environment factor is plotted on the horizontal axis and the parking factor on the vertical axis. This figure shows the result for three types of common space, in terms of whether parking and the environment are viewed as positive or negative characteristics. Results for different types of residents are grouped into circles.

PSO results were more widely scattered than the results for the other two types of common space. The factor scores for PSO are mainly distributed in the 2nd quadrant, indicating satisfaction with parking and dissatisfaction with environment. Moreover, results were arranged close to the axis of parking.

Factor scores for PSES are arranged around the origin, but with a slight bias toward the positive direction. Results for PSES lie approximately between PSO and ESO with regard to parking: PSES residents show a more neutral attitude towards parking. In particular, two PSES residents gave a high evaluation of the environment and two other residents gave high scores for parking, as can be seen in the first quadrant.

Many factor scores for ESO were located in the negative parking direction, but with more neutral environment scores. They were more commonly

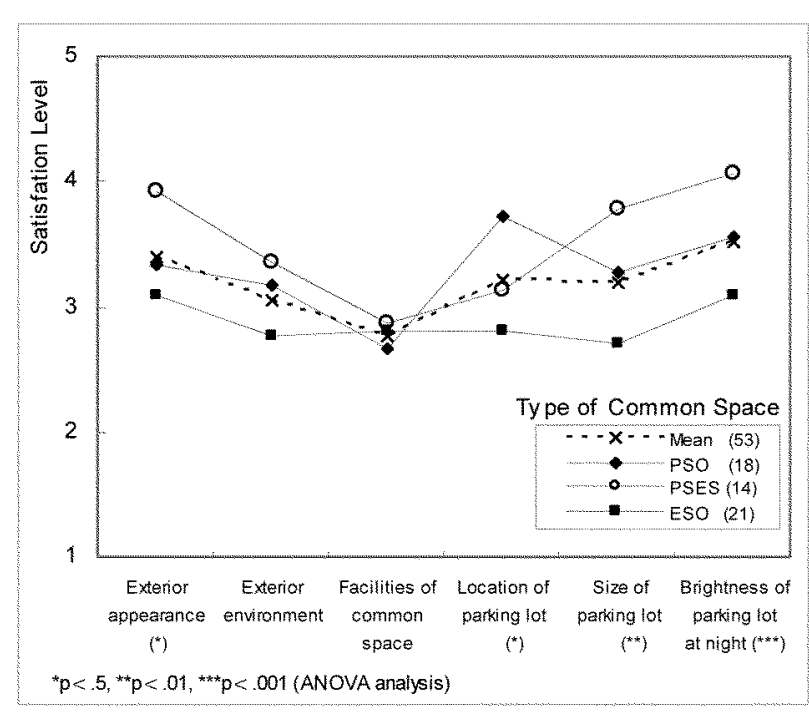

Fig.5. Satisfaction with Common Space by Residents

Table 9. Factor Analysis of Common Space

\begin{tabular}{c|l|c|c}
\hline & \multicolumn{1}{|c|}{ Question } & Factor 1 & Factor 2 \\
\hline \multirow{4}{*}{$\mathrm{E}$} & Exterior appearance & .828 & .372 \\
\cline { 2 - 4 } & Exterior environment & .764 & .380 \\
\cline { 2 - 4 } & Facilities of common space & .691 & -.228 \\
\cline { 2 - 4 } & Brightness of parking lot at night & .538 & .263 \\
\hline \multirow{2}{*}{$\mathrm{P}$} & Size of parking lot & .354 & .859 \\
\cline { 2 - 4 } & Location of parking lot & .032 & .851 \\
\hline \multicolumn{2}{c}{ Cumulative Contribution } & 2.940 & 1.089 \\
\hline \multicolumn{2}{c}{ C: } & 36.036 & 67.156 \\
\hline
\end{tabular}

. Environment, P : Parking

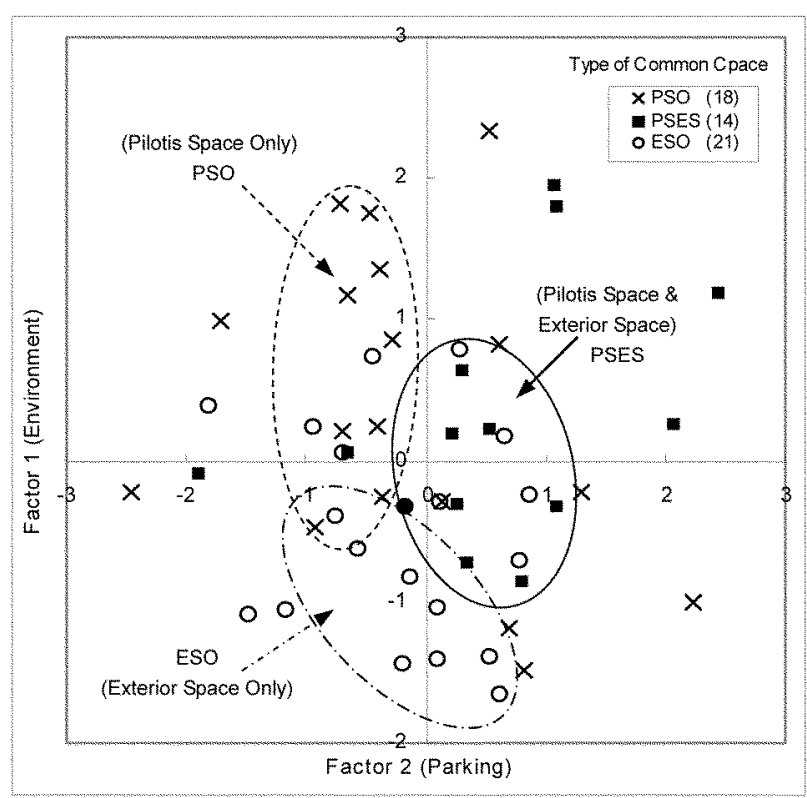

Fig.6. Distribution of Scores Obtained by Factor Analysis

located in the fourth quadrant than factor scores for the other types of common space. In cases where common space is the only exterior space, better planning regarding the use of exterior space appears to be required.

\section{Conclusion}

Not only is the common space in apartments an intermediate area between private and public space, it 
also plays the role of communal space for residents in apartment housing. This study was conducted on the planning and use of the common space of private rental apartments in Okinawa, Japan, focusing on the location of common space for two types of building: pilotis style and non-pilotis style.

With the rapid increase in the rate of automobile use in Okinawa, the provision of common space for parking has become a basic factor in planning. In the study, architectural drawings and information were requested for 110 private rental apartments in Okinawa, and a questionnaire sent to residents was analyzed. The results were as follows:

First, the number of pilotis style apartments has increased since 1996 reaching double the number of non-pilotis style buildings by 2006. Pilotis style apartments without exterior space tend to be built on small sites and have a higher building coverage ratio than apartments with planned exterior space. Therefore, it can be concluded that the establishment of pilotis or non-pilotis style buildings is influenced by the site area and the exterior space. Pilotis space was categorized into six forms by topographic features and the open or closed quality of the space.

Second, the types of common space were classified into four building type groups by pilotis structure and location of common space: no common space, pilotis space only, shared pilotis space and exterior space, and exterior space only. Pilotis space is substituted for exterior space of non-pilotis style buildings and supports the functional use of exterior space.

Third, the main function of common space is for parking. The rapid increase in the level of car ownership in Okinawa means that more space is required for parking, and pilotis style buildings are suitable for the provision of parking spaces. The number of car lots available is estimated to be 1 to 1.5 per unit, which is a larger ratio than in other areas of Japan.

Finally, the authors evaluated the satisfaction with common space. PSES residents (shared pilotis space and exterior space) were more satisfied and ESO residents (exterior space only) were less satisfied with common space than other residents. The interdependence of six variables indicating satisfaction with common space focused on two principal factors: parking and external environment. Residents of apartments with three types of common space showed different tendencies of satisfaction with parking and the environment. PSO residents regarded parking positively and the environment negatively, PSES residents were neutral toward parking but regarded the environment positively, and ESO residents regarded parking negatively and the environment neutrally.

\section{Notes}

1. Ref. 5 .

2. Ref. 7.

3. In 2000 , the number of cars owned per household in Okinawa was 1.77 , while it averaged 1.57 in the rest Japan. In 2000, the yearly rate of increase in the number of cars per household in Okinawa was $3.98 \%$, while it was $2.95 \%$ in other areas of Japan.

4. Ref. 8 .

5. Ref. 6.

6. Ref. 7.

7. The original title, [Chintai] 住宅 [Jutaku] 計画 [Keikaku] の [No] 企画 $[\mathrm{Kikaku}]$ と $[\mathrm{To}]$ 建築 $[\mathrm{Kenchiku}$ 知識 [Chishiki], was translated as "Plans and building knowledge of rental housing schemes" by the authors.

\section{References}

1) Adachi, M. and Sakamoto, K. (1999) Typological composition of arrangement of housing units and exterior spaces-Collective form in contemporary Japanese housing (2). J. Archit. Plann. Environ. Eng., AIJ, No. 522, pp.179-185, Dec.

2) Adachi, M. and Sakamoto, K. (2000) Typological composition of connection of housing units with exteriors space-collective form in contemporary Japanese housing (4). J. Archit. Plann. Environ. Eng., AIJ, No. 538, pp.101-108, Dec.

3) Chen, L. (1985) A study on structure and utilization of outdoor common space in apartment houses supplied by private enterprises. J. Archit. Plann. Environ. Eng., AIJ, No. 359, pp.62-73, Jan.

4) Nam, T., Usami, M., Sugiyama, S., and Tokuono, T. (2007) The parking space installation methods in the apartment housings located in built-up areas. J. Archit. Plann. AIJ, No. 614, pp.17-24, Apr.

5) Sato, K. and Miyasaka, S. (1996) Investigation on masonry in Okinawa District: influence of the physical environment on types of structure in part 1 and part 2. Summaries of technical papers of the Annual Meeting of the Architectural Institute of Japan.

6) Suzuki, M., Nakanishi, S., and Hattori, M. (1999) The open space of multifamily housing in Tokyo built-up area. J. Archit. Plann. Environ. Eng., AIJ, No. 519, pp.123-130, May.

7) Tanoue, K., Ogura, N., and Fukushima, S. (1999) Spatial characteristics of the pilotis-type detached housing analyzing by housing needs and dwelling usage. J. Archit. Plann. Environ. Eng., AIJ, No. 522, pp.147-153, Aug.

8) Terauchi, M., Sakamoto, K., and Okuyama, S. (1997) Articulation and layout of exterior space-composition of exterior space in Japanese contemporary architecture. J. Archit. Plann. Environ. Eng., AIJ, No. 491, pp.91-98, Jan.

9) Akiyama, H. (2005) 賃貸 [Chintai] 住宅 [Jutaku] 計画 [Keikaku] の [No] 企画 $[\mathrm{Kikaku}]$ と [To] 建築 [Kenchiku] 知識 [Chishiki]. Shukan Jutaku Shinbun. 